\title{
PENERAPAN ALGORITMA APRIORI PADA DATA PENJUALAN KOSMETIK DI TOKO SHARLY KOTA LUBUKLINGGAU
}

\author{
Andri Anto Tri Susilo ${ }^{1}$, Lukman Sunardi ${ }^{2}$, Yuliani Waruwu ${ }^{3}$ \\ ${ }^{123}$ Program Studi Informatika - Universitas Bina Insan Lubuklinggau \\ Email:1 andri_anto_tri_susilo@univbinainsan.ac.id, ${ }^{2}$ lukmansunardi@univbinainsan.ac.id, \\ 3yuliani@gmail.com
}

\begin{abstract}
Abstrak
Di bidang bisnis hasil implementasi data mining algoritma Apriori dapat membantu para pebisnis dalam pengambilan keputusan terhadap apa yang berhubungan dengan persediaan barang.Transaksi penjualan sehari-hari menimbulkan penumpukan data, karena banyaknya transaksi penjualan yang terjadi setiap harinya. Upaya peningkatkan penjualan sebuah agen kosmetik dapat dilakukan dengan cara mengolah data transaksi yang menumpuk menjadi sebuah informasi yang berguna. Analisis transaksi penjualan bertujuan untuk merancang strategi penjualan atau pemasaran yang efektif dengan memanfaatkan data transaksi penjualan yang telah tersedia. Selain itu penggunaan teknik analisis ini juga dapat menemukan pola berupa produkproduk yang sering dibeli bersamaan dalam sebuah transaksi. Pengolahan data untuk memperoleh informasi mengenai pola-pola dapat dilakukan dengan datamining, yaitu Association Rules.Algoritma Apriori yang merupakan salah satu metode Association Rules cocok untuk diterapkan bila terdapat beberapa hubungan item yang ingin dianalisis. Algoritma Apriori mampu menggali informasi pada data dan dapat menampilkan hubungan antar atributnya. penelitian ini akan menerapkan Algoritma pada bidang bisnis dan penentuan pola pembelian kosmetik. Pengolahan datamining untuk mengetahui kosmetik apa saja yang dibeli oleh para konsumen, dapat dilakukan dengan teknik analisis dari kebiasaan membeli komsumen.
\end{abstract}

Kata Kunci : Data Minning,Informasi,Transaksi,Algortima Apriori

\begin{abstract}
In the business sector, for example, the results of implementing the Apriori algorithm for data mining can help business people make decisions about what is related to inventory. Daily sales transactions cause data buildup, due to the large number of sales transactions that occur every day. Efforts to increase sales of a cosmetics agent can be done by processing transaction data that accumulates into useful information. Sales transaction analysis aims to design effective sales or marketing strategies by utilizing available sales transaction data. In addition, the use of this analysis technique can also find patterns in the form of products that are often bought together in a transaction. Data processing to obtain information about patterns can be done by datamining, namely the Association Rules. A priori algorithm which is one of the Association Rules methods is suitable to be applied when there are several item relationships that want to be analyzed. Apriori algorithm is able to dig up information on data and can display the relationships between its attributes. This research will apply the algorithm in the business field and determine the purchase pattern of cosmetics. Datamining processing to find out what cosmetics are purchased by consumers, can be done with analysis techniques from consumer buying habits.
\end{abstract}

Keywords: Data Minning, Information, Transactions, Algorithm Apriori 


\section{PENDAHULUAN}

Perkembangan Data mining saat ini telah diimplementasikan keberbagai bidang, diantaranya dalam bidang bisnis atau perdagangan,bidang pendidikan, dan telekomunikasi.Di bidang bisnis misalnya hasil implementasi data mining algoritma Apriori dapat membantu para pebisnis dalam pengambilan keputusan terhadap apa yang berhubungan dengan persediaanbarang [1]. Toko Kosmetik Sharly adalah salah satu agen dan took kosmetik yang berada dikota Lubuklinggau,agen kosmeti kini mengadakan penjualan alat - alat kosmetik, dari penjualan tersebut mengakibatkan adanya transaksi jual beli yang membuat took kosmetik Sharly mempunyai berbagai data seperti data persediaan barang dan data transaksi penjualan sehari-hari.Transaksi penjualan sehari-hari menimbulkan penumpukan data, karena banyaknya transaksi penjualan yang terjadi setiap harinya. Upaya peningkatkan penjualan sebuah agen kosmetik dapat dilakukan dengan cara mengolah data transaksi yang menumpuk menjadi sebuah informasi yang berguna. Informasi yang berguna dapat dimanfaatkan untuk membuat sebuah kebijakan bisnis, yaitu dengan menerapkan informasi tesebut menjadi sebuah strategi bisnis.Analisis transaksi penjualan bertujuan untuk merancang strategi penjualan atau pemasaran yang efektif dengan memanfaatkan data transaksi penjualan yang telah tersedia di Toko Kosmetik Sharly. Selain itu penggunaan teknik analisis ini juga dapat menemukan pola berupa produkproduk yang sering dibeli bersamaan dalam sebuah transaksi.

Pengolahan data untuk memperoleh informasi mengenai pola-pola dapat dilakukan dengan datamining, yaitu Association Rules. Algoritma Apriori yang merupakan salah satu metode Association Rules cocok untuk diterapkan bila terdapat beberapa hubungan item yang ingin dianalisis [1].

Berdasarkan hasil penelitian sebelumnya menunjukkan bahwa algoritma Apriori mampu menggali informasi pada data dan dapat menampilkan hubungan antar atributnya.Oleh karena itu, penelitian ini akan menerapkan Algoritma pada bidang bisnis dan penentuan pola pembeliankosmetik.Pengolahan datamining untuk mengetahui kosmetik apa saja yang dibeli oleh para konsumen, dapat dilakukan dengan teknik analisis dari kebiasaan membeli komsumen.

\section{TINJAUAN PUSTAKA}

\subsection{Penelitian Terdahulu}

Pertama, penelitian yang dilakukan Achmad Zaenal Hidayat dan Wijanarto pada tahun 2017 dengan judul "Penerapan Algoritma Apriori Untuk Menentukan Strategi Penjualan Pada Rumah Makan "Dapur Emak" Pati". Pada penelitian ini digunakan Algoritma Apriori digunakan untuk meningkatkan penjualan pada Rumah Makan "Dapoer emak" Pati. Sistem ini diharapkan dapat membantu pemilik Rumah Makan "Dapoer emak" untuk merencanakan strategi pejualan produk menu yang mereka tawarkan. Perencanaan itu dilakukan dengan cara memberikan promo "Paket Hemat" sebagai pilihan untuk konsumen. Algoritma Apriori salah satu dari bagian Analisis Asosiasi. Algoritma ini dipilih untuk menghasilkan aturan-aturan asosiasi dari hasil transaksi penjualan menu pada Rumah Makan "Dapoer emak". Dalam menentukan aturan asosiasi ini, diperlukan identifikasi frequent itemset. Hal ini merupakan kombinasi menu yang kemungkinan dibeli para konsumen. Penentuan ini dimulai dari 1 item sampai dengan 3 item. Selanjutnya, itemset tersebut akan menghasilkan aturanaturan asosiasi beserta nilai confidence. Jika nilai confidence sama dengan atau di atas 
nilai min-confidence yang telah didefinisikan sebelumnya maka kombinasi menu itu akan diikutkan dengan promo "Paket Hemat". Selain itu konsumen juga langsung biasa memilih menu yang sudah terdaftar dalam menu "Paket Hemat" yang sudah terdaftar. Diharapkan dengan adanya promo "Paket Hemat" ini, penjualan di Rumah Makan "Dapoer Emak" dapat meningkat dari sebelumnya [17]

Kedua, penelitian yang dilakukan oleh Witri Widiawati, pada tahun 2017 dengan judul "Penerapan Algoritma Apriori Dengan Analisa Keranjang Belanja Untuk Sistem Persedian Alat-Alat Kesehatan" Aktivitas transaksi dan pelayanan terhadap konsumen di CV Dasacipta Sarana Medika Surakarta, setiap harinya semakin lama semakin tinggi. Sehingga tanpa disadari hal ini dapat menimbulkan tumpukan data yang semakin besar. Dalam menjalankan aktivitasnya, sudah menggunakan jasa teknologi komputer sebagai alat dalam pengimputan data, pengolahan serta pencetakan hasil pengolahan data berupa informasi yang diinginkan. Namun dalam pengolahan data masih menggunakan aplikasi-aplikasi yang sederhana. Walaupun hingga saat ini aktivitas pelayanan dan transaksi belum mengalami kendala yang berarti, tentu keadaan ini suatu saat menjadi faktor penghambat dalam meningkatkan pelayanan seiring semakin banyaknya transaksi dan jenis item dan itemsets transaksi yang terjadi dan tersimpan dalam kurun waktu tertentu, sehingga menyulitkan pihak CV Dasacipta Sarana Medika dalam menganalisa jenis item dan itemsets barang mana yang paling diminati atau tidak diminati oleh konsumen. Market Basket Analysis merupakan salah satu teknik dari data mining yang mempelajari tentang perilaku kebiasaan konsumen dalam membeli barang secara bersamaan dalam satu waktu. Teknik tersebut bisa diterapkan dalam data yang sangat besar seperti data transaksi penjualan. Data mining diartikan sebagai menambang data atau upaya untuk menggali informasi yang berharga dan berguna pada database yang sangat besar. Hal terpenting dalam teknik data mining adalah aturan untuk menemukan pola frekuensi tinggi antar himpunan itemsets yang disebut fungsi Association Rules (aturan asosiasi). Proses pencarian asosiasi atau hubungan antar item data ini diambil dari suatu basis data relasional. Proses tersebut menggunakan algoritma apriori. Alasan mengapa menggunakan algoritma apriori karena algoritma apriori sangat efisien dan dapat mempercepat proses pembentukan kecenderungan pola kombinasi itemset. Penerapan algoritma apriori, membantu dalam membentuk kandidat kombinasi item, kemudian dilakukan pengujian apakah kombinasi tersebut memenuhi parameter support dan confidence minimum yang merupakan nilai ambang yang diberikan oleh pengguna.

Ketiga, penelitian yang dilakukan oleh Ulvah pada tahun 2018 dengan judul "Implementasi Algoritma Apriori Aturan Keterkaitan Data Untuk Analisa Keranjang Belanja Sistem Persediaan Obat Pada Apotik Perdos Farma Makassar" penelitian penelitian ini bertujuan untuk meningkatkan sistem informasi persediaan obat pada apotek perdos farma makassar, dengan melakukan analisa keranjang belanja menggunakan metode asosiasi dengan mengimplementasi algoritma Apriori didalamnya. Dimana kombinasi itemset transaksi penjualan obat dan alat kesehatan pada Apotek Perdos farma makassar menghasilkan 6 rules terbaik dengan nilai minimum support sebesar $15 \%$, dan nilai confidence tertinggi dari 6 rules terbaik sebesar $72 \%$ dengan tingkat keakuratan nilai lift tertinggi 6,27\%. Dari hasil tersebut dapat diketahui bahwa terdapat 14 jenis obat yang 
paling banyak terjual berdasarkan 100 transaksi penjualan dari 312 jenis obat dan alat kesehatan pada Apotek Perdos Farma Makassar.

\subsection{Pengertian Penerapan}

Penerapan (implementasi) adalah bermuara pada aktivitas, aksi, tindakan, atau adanya mekanisme suatu sistem.Implementasi bukan sekedar aktivitas, tetapi suatu kegiatan yang terencana dan untuk mencapai tujuan kegiatan [2].

Penerapan (implementasi) adalah perluasan aktivitas yang saling menyesuaikan proses interaksi antara tujuan dan tindakan untuk mencapainya serta memerlukan jaringan pelaksana, birokrasi yang efektif. 9 Berdasarkan pengertianpengertian tersebut dapat disimpulkan bahwa kata penerapan (implementasi) bermuara pada aktifitas, adanya aksi, tindakan, atau mekanisme suatu system. Ungkapan mekanisme mengandung arti bahwa penerapan (implementasi) bukan sekedar aktifitas, tetapi suatu kegiatan yang terencana dan dilakukan secara sungguhsungguh berdasarkan acuan norma tertentu untuk mencapai tujuan kegiatan [3]

\subsection{Algoritma}

Sistem Para ahli bahasa menemukan kata algorism berasal dari nama cendikiawan muslim yang terkenal yaitu Abu Ja'far Muhammad Ibnu Musa Al-Khuwarijmi (AlKhuwarijmi dibaca oleh orang Barat menjadi algorism) dalam bukunya yang berjudul Kitab Aljabar Wal-muqabala, yang artinya "Buku Pemugaran dan Pengurangan" (The book of restoration and reduction). Dari judul buku itu kita memperoleh kata "aljabar" (algebra). Perubahan dari kata algorism menjadi algorithm muncul karena kata algorism sering dikelirukan dengan arithmetic sehingga akhiran -sm berubah menjadi -thm [4].

Algoritma adalah prosedur komputasi yang mengambil beberapa nilai atau kumpulan nilai sebagai input kemudian di proses sebagai output sehingga algoritma merupakan urutan langkah komputasi yang mengubah input menjadi output [5]

\subsection{Algoritma Apriori}

Apriori adalah algoritma yang digunakan dalam melakukan pencarian frequent itemset untuk mendapatkan aturan asosiasi. Sesuai dengan namanya, algortima ini menggunakan prior knowledge mengenai frequent itemset properties yang telah diketahui sebelumnya untuk memproses informasi selanjutnya. Apriori menggunakan pendekatan secara iterative yang disebut juga sebagai level-wish search dimana k-itemset digunakan untuk mencari $(\mathrm{k}+1)$-itemset. Pertama-tama dicari set dari frequent 1-itemset, set ini dinotasikan sebagai L1. L1 yaitu large itemset pertama yang digunakan untuk menemukan L2, kemudian set dari frequent 2-itemset digunakan untuk menemukan L3, dan seterusnya sampai tidak ada lagi frequent $\mathrm{k}-$ itemset yang dapat ditemukan. Large itemset adalah itemset yang sering terjadi atau itemset-itemset yang sudah melewati batas minimum support yang telah ditentukan [6].

Adapun dua proses utama yang dilakukan dalam algoritma apriori, yaitu:

1. Join (penggabungan). Pada proses ini setiap item dikombinasikan dengan item yang lainnya sampai tidak terbentuk kombinasi lagi.

2. Prune (pemangkasan). Pada proses ini, hasil dari item yang telah dikombinasikan tadi lalu dipangkas dengan menggunakan minimum support yang telah ditentukan oleh user [7] 
Analisis asosiasi atau association rule mining adalah teknik data mining untuk menemukan aturan asosiatif antara suatu kombinasi item. Contoh aturan asosiatif dari analisis pembelian di suatu pasar swalayan adalah dapat diketahuinya berapa besar kemungkinan seorang pelanggan membeli roti bersama dengan susu (contoh). Dengan pengetahuan tersebut, pemilik pasar swalayan dapat mengatur penempatan barangnya atau merancang kampanye pemasaran dengan memakai kupon diskon untuk kombinasi barang tertentu, aturan yang menyatakan asosiasi antara beberapa aribut sering disebut affinity analiysis atau Market Basket Analysis [8].

Metodologi dasar analisis asosiasi terbagi menjadi dua tahap [8] :

1) Analisis pola frekuensi tinggi

Tahapan ini mencari kombinasi item yang memenuhi syarat minimum dari nilai support dalam database. Nilai support sebuah item diperoleh dengan rumus berikut.

$$
\operatorname{Support}^{-}(A)=\frac{\text { Jumlah transaksi mengandung A }}{\text { Total Transaksi }}
$$

Sementara itu, nilai support dari 2 item diperoleh dari rumus 2 berikut.

Support $(A, B)=\mathrm{P}(\mathrm{A} \cap \mathrm{B})$ $\operatorname{Support}(A, B)=\sum$ Transaksi mengandung $A \operatorname{dan} B$

$$
\sum \text { Transaksi }
$$

\section{2) Pembentukan aturan asosiasi}

Setelah semua pola frekuensi tinggi ditemukan, barulah dicari aturan asosiasi yang memenuhi syarat minimum untuk confidence dengan menghitung confidence aturan asosiatif $\mathrm{A} \rightarrow \mathrm{B}$.

Nilai confidence dari aturan $\mathrm{A} \rightarrow \mathrm{B}$ diperoleh dari rumus berikut.

\section{Confidence $=\mathrm{P}(B \mid A)=$ $\sum$ Transaksi mengandung $A$
dan $B$ \\ $\sum$ Transaksi mengandung $A$}

\subsection{Penjualan}

Penjualan sering disalah artikan dengan istilah pemasaran, bahkan ironisnya ada yang menganggap sama pengertian penjualan dan pemasaran. Kesalahpahaman tidak hanya pada praktek penjualan tetapi juga pada struktur organisasi perusahaan. Pada hakekatnya kedua istilah tersebut memiliki arti dan ruang lingkup yang berbeda. Pemasaran memiliki arti yang lebih luas meliputi berbagai fungsi perusahaan, sedangkan penjualan merupakan bagian dari kegiatan pemasaran itu sendiri. Dengan demikian penjualan adalah tidak sama dengan pemasaran [9].

\section{METODOLOGI PENELITIAN}

\subsection{Analisa Sistem}

\subsubsection{Analisa Sistem yang Berjalan}

Transaksi penjualan sehari-hari pada took kosmetik Sharly menimbulkan penumpukan data, karena banyak nya transaksi penjualan yang terjadi setiap harinya. Upaya peningkatkan penjualan sebuah agen kosmetik dapat dilakukan dengan cara mengolah data transaksi yang menumpuk menjadi sebuah informasi yang berguna.Informasi yang berguna dapat dimanfaatkan untuk membuat sebuah kebijakan bisnis, yaitu dengan menerapkan informasi tesebut menjadi sebuah strategi bisnis. Analisis transaksi penjualan bertujuan untuk merancang strategi penjualan atau pemasaran yang efektif dengan memanfaatkan data transaksi penjualan yang telah tersedia di took kosmetik Sharly. Selain itu penggunaan teknik analisis ini juga dapat menemukan pola berupa produk-produk yang sering dibeli bersamaan dalam sebuah transaksi. 


\subsubsection{Alternatif Pemecahan Masalah}

Berdasarkan sistem yang berjalan maka alteratif yang ditawarkan penulis untuk menerapkan Algoritma Apriori pada bidang bisnis dan penentuan pola pembelian kosmetik.Pengolahan data mining untuk mengetahui kosmetik apa saja yang dibeli oleh para konsumen, dapat dilakukan dengan teknik analisis dari kebiasaan membeli komsumen, dari hasil penerapan algoritma tersebut akan menghasilkan informasi sebagai acuan keputusan strategis pada took kosmetik Sharly.

\subsection{Perancangan Sistem}

\subsubsection{Perancangan dengan UML}

Rancangan hasil analisis pada penelitian ini, dibuat Penulis menggunakan diagram UML. Dimana penulis akan memakai use case diagram, activity diagram, class diagram, dan sequence diagram.

\subsubsection{Use Case Diagram}

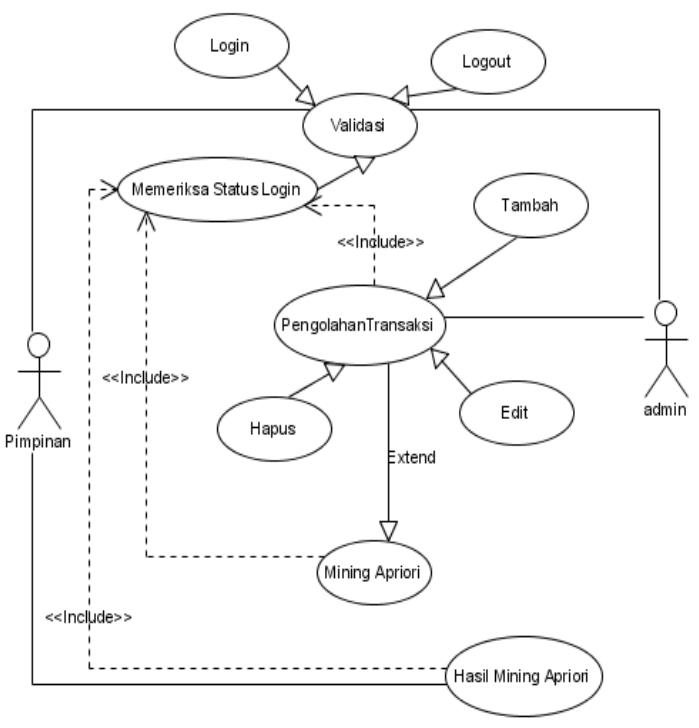

Gambar 1. Use case diagram

\section{HASIL DAN PEMBAHASAN \\ 4.1 Hasil \\ Dari perancangan system maka hasil} penelitian ini berupa penerapan algoritma apriori pada data penjualan kosmetik di took Sharly, yang terdiri dari :

1. Halaman login administrator, adalah halaman yang dimana user administrator melakukan proses login untuk masuk kehalaman home administrator.

2. Halaman home administrator, adalah halaman untuk user administrator yang telah berhasil melakukan login.

3. Halaman pengolahan data transaksi, adalah halaman dimana administrator bias mengolah data transaksi, dihalaman ini admin bias melakukan tambah data transaksi dan hapus data transaksi.

4. Halaman tambah transaksi, dihalaman ini admin melakukan proses penambahan data transaksi.

5. Halaman hapus transaksi, dihalaman ini admin melakukan proses hapus pada data transaksi.

6. Halaman proses mining apriori, adalah halaman dimana administrator bias melakukan proses mining menggunakan algoritma apriori terhadap data penjualan yang ada.

7. Halaman hasil mining (rule), adalah halaman hasil mining menggunakan algoritma apriori terhadap data penjualan.

8. Halaman login pimpinan, adalah halaman yang dimana user pimpinan atau pemilik took melakukan proses login untuk masuk kehalaman home pimpinan.

9. Halaman home pimpinan, adalah halaman untuk user pimpinan yang telah berhasil melakukan login

10. Halaman hasil mining (rule), adalah halaman hasil mining menggunakan 
algoritma apriori terhadap data penjualan, pada halaman ini user pimpinan melihat hasil mining dari data penjualan pada took sharly kosmetik.

\subsection{Pembahasan}

\subsubsection{Halaman Awal}

1. Halaman Login Administrator

Halaman login administrator adalah halaman pertama yang di tampilkan oleh aplikasi, dihalaman ini admin harus melakukan login sebelum masuk kehalaman home administrator, untuk lebih jelas pada gambar 2

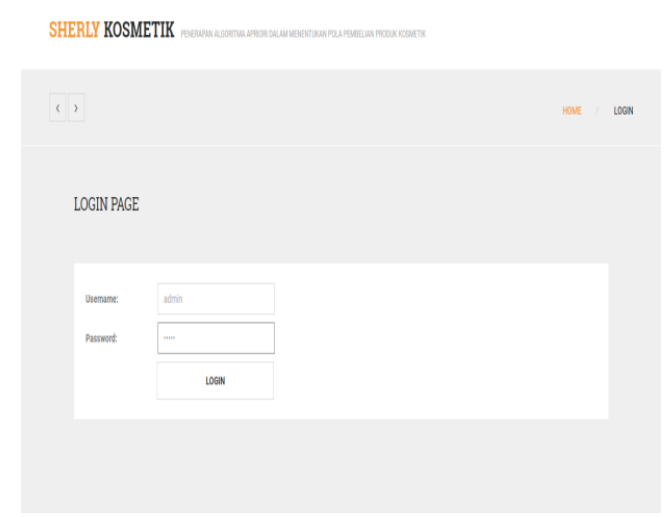

Gambar 2. Halaman Login Administrator

\section{Halaman Home}

Halaman home adalah halaman yang ditampilkan jika administrator berhasil melakukan autentifikasi login, untuk lebih jelas pada gambar 3 .

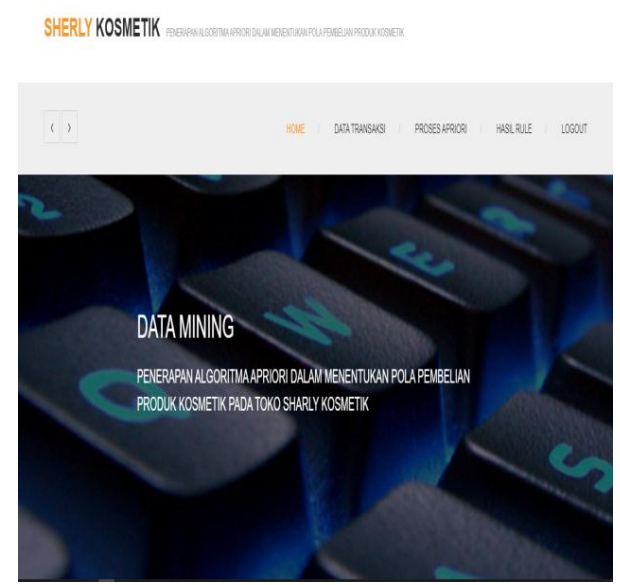

Gambar 3. Halaman Home Administrator
3. Halaman Pengolahan Data Transaksi

Pada halaman ini administrator bias melakukan pengolahan data hasil transaksi, untuk lebih jelas bisa di lihat pada gambar 4

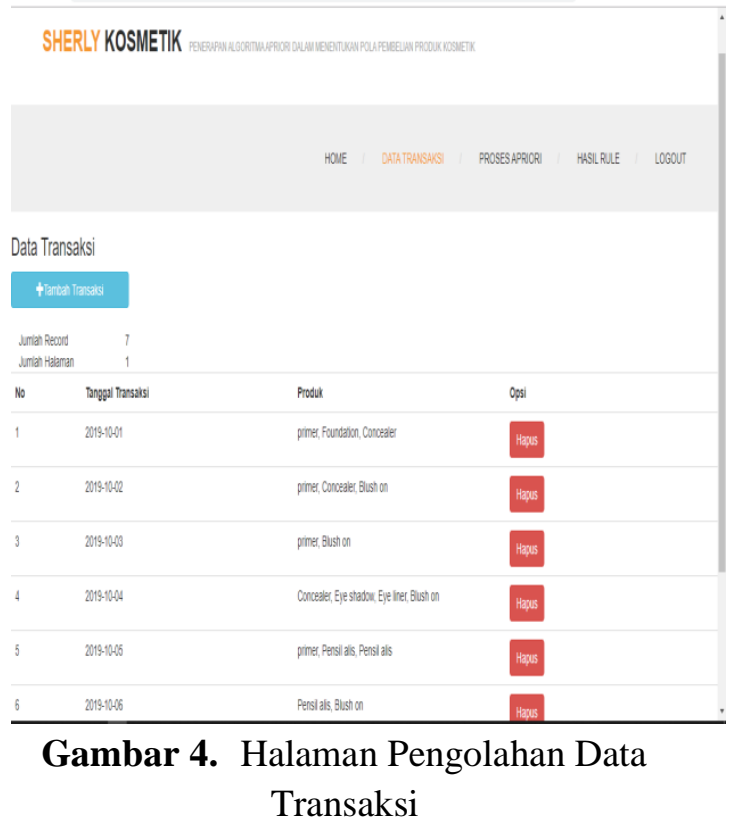

4. Halaman Tambah Data Hasil Transaksi

Pada halaman ini administrator bias melakukan penambahan data transaksi, untuk lebih jelas bisa di lihat pada gambar 5 .

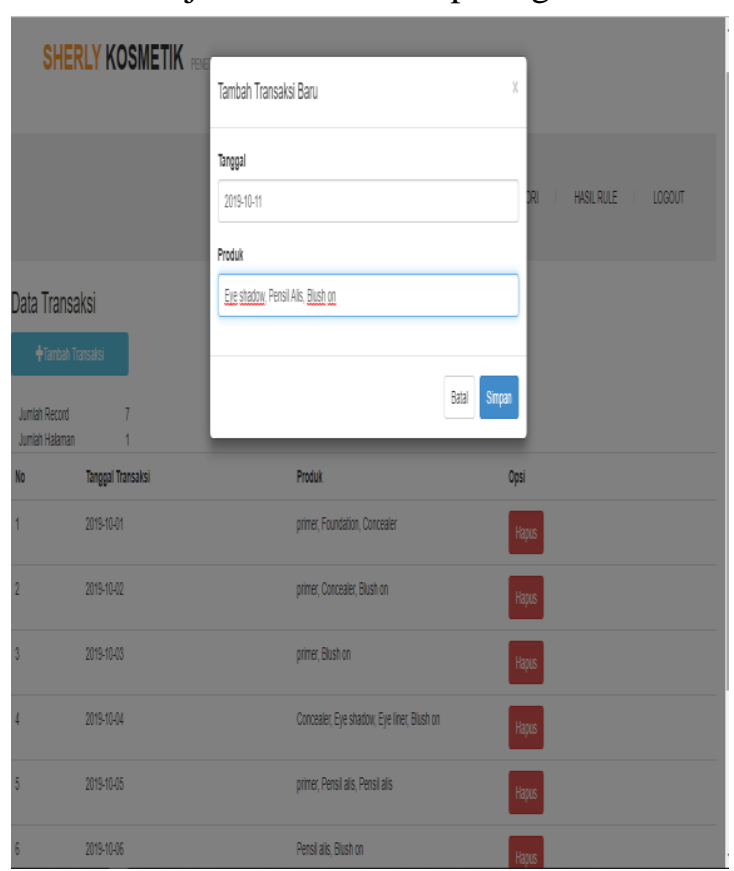

Gambar 5. Halaman Tambah Data Transaksi 
5. Halaman Hapus Data Transaksi

Pada halaman ini administrator bias melakukan menghapus data transaksi, untuk lebih jelas bisa di lihat pada gambar 6 .

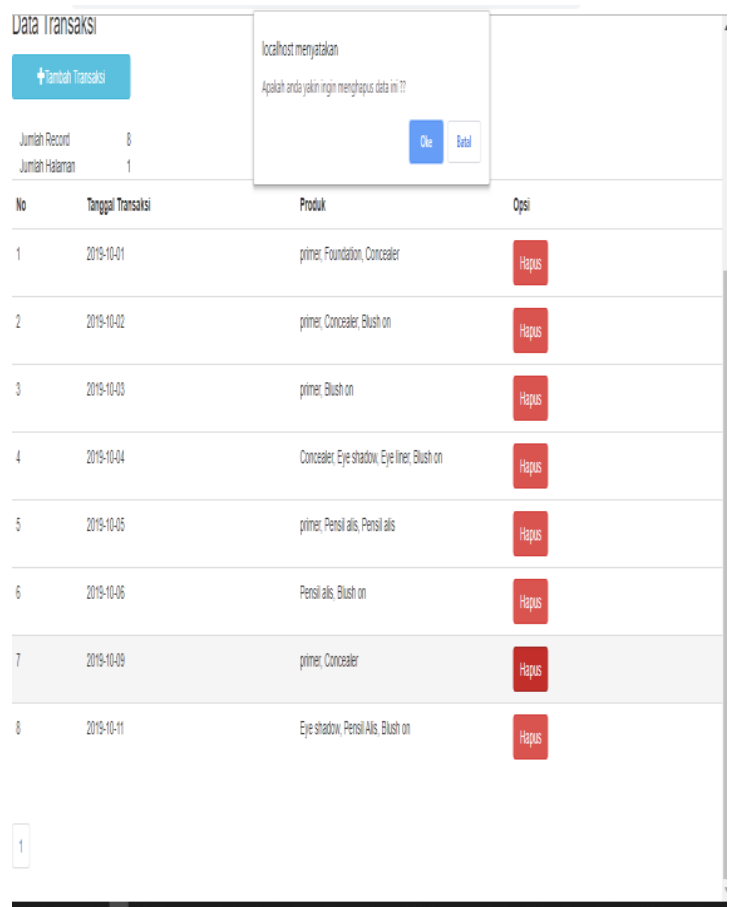

Gambar 6. Halaman Hapus Data Transaksi

6. Halaman Proses Mining Apriori

Pada halaman ini administrator bias melakukan proses mining, untuk lebih jelas bisa di lihat pada gambar 7 .

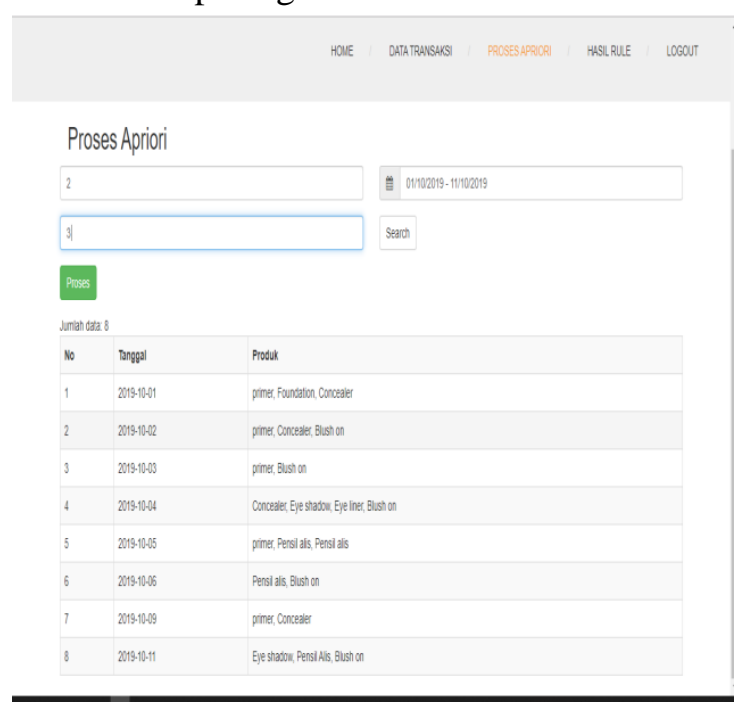

Gambar 7. Halaman Proses Mining Apriori
7. Halaman Hasil Mining Apriori

Pada halaman ini administrator bias melihat hasil mining terhadap data penjualan, untuk lebih jelas bisa di lihat pada gambar 8 .

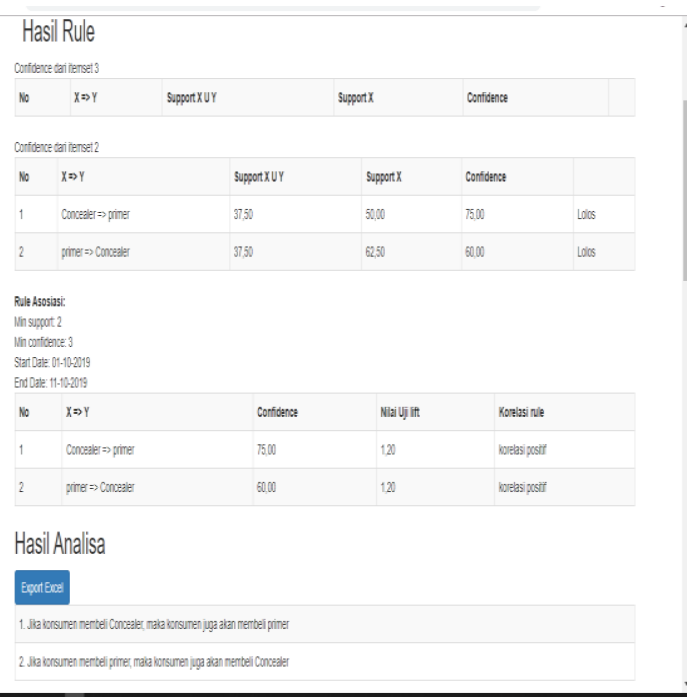

Gambar 8. Halaman Hasil Mining Apriori

8. Halaman Login Pimpinan

Halaman login pimpinan adalah halaman pimpinan melakukan login sebelum masuk kehalaman home pimpinan, untuk lebih jelas pada gambar 9 .

\section{SHERTV KOSMETKK}

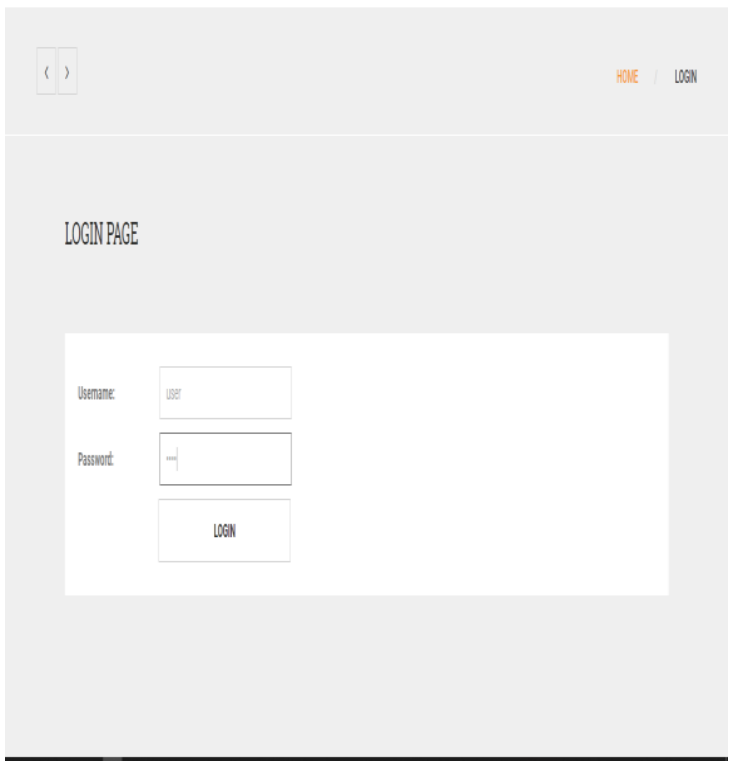

Gambar 9. Halaman Login Pimpinan 
9. Halaman Home Pimpinan

Halaman home adalah halaman yang ditampilkan jika user pimpinan berhasil melakukan autentifikasi login, untuk lebih jelas pada gambar 10

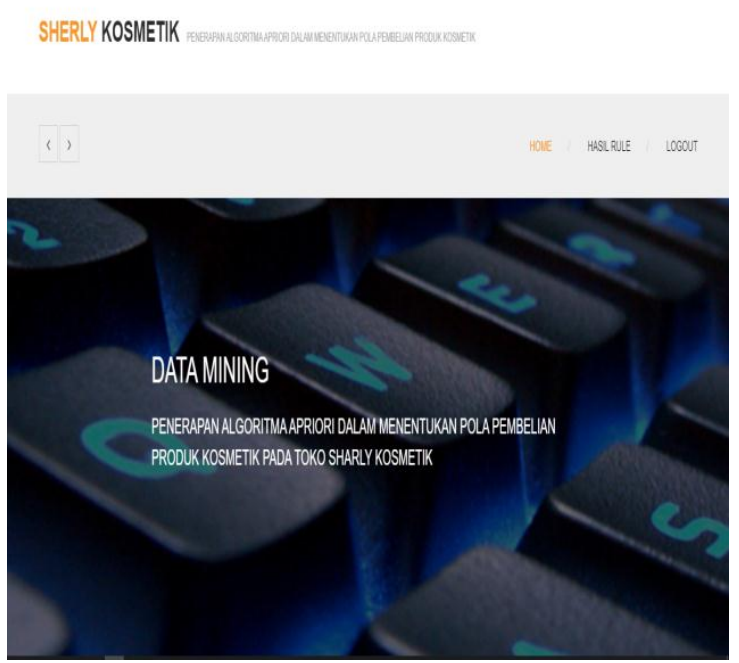

Gambar 10. Halaman Home Piimpinan

10. Halaman Lihat Hasil Mining Apriori Pada halaman ini pimpinan bias melihat hasil mining terhadap data penjualan, untuk lebih jelas bisa di lihat pada gambar 11

\section{SHERLY KOSMETIK}

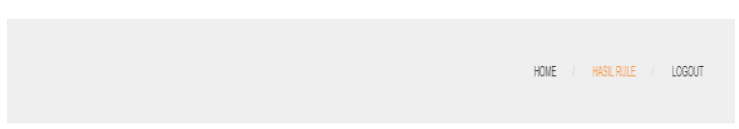

Hasil Rule

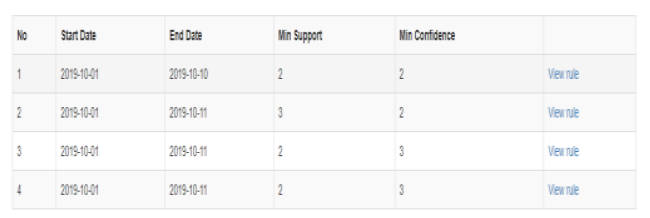

Gambar 11. Halaman Lihat Hasil Mining Apriori

\section{KESIMPULAN DAN SARAN}

\subsection{Kesimpulan}

Berdasarkan hasil dari analisis, perancangan, dan evaluasi terhadap penerapan algoritma apriori pada data penjualan kosmetik di toko Sharly, dapat diambil kesimpulan sebagai berikut :

1. Dengan adanya sistem ini maka proses analisis data transaksi penjualan menjadi lebih efisien.

2. Pemilik took dapat dengan mudah mengatur penempatan barang sesuai dengan hasil analisis berdasarkan apriori.

\section{SARAN}

Dengan adanya penelitian ini, diharapkan adanya perbaikan maupun pengembangan pada penerapan algoritma apriori pada data penjualan kosmetik di toko Sharly dan saran dari penelitian yang telah dilakukan diantaranya adalah sebagai berikut :

1. Perlu ditambahkan fitur lain yang dapat lebih membantu pemilik took dalam penjualannya

2. Ditambahkan lagi untuk pengembangan supaya berbentuk aplikasi android agar lebih fleksibel penggunaannya.

\section{DAFTAR PUSTAKA}

[1] Kennedi Tampubolon, Hoga Saragih, Bobby Reza. 2013. Implementasi Data Mining Algoritma Apriori Pada Sistem Persediaan Alat-Alat Kesehatan. Majalah Ilmiah Informasi dan Teknolog iIlmiah (INTI). Volume : I, Nomor : 1.

[2] Usman, Basyiruddin. 2012. Media Pendidikan. Jakarta: Ciputat Press.

[3] Setiawan, Guntur. 2014. 
Pembangunan. Bandung:Remaja

Rosdakarya Offset

[4] Munir, Rinaldi. 2011.Algoritma dan pemrograman :Dalam bahasa pascal dan C, Informatika, Bandung.

[5] Cormen, Thomas H. 2009. Introduction to Algorithms". The MIT Press.

[6] Hapsari Dita Anggraeni, Ragil Saputra, and Beta Noranita, "Aplikasi Data Mining Analisis Data Transaksi Penjualan Obat Menggunakan Algoritma Apriori( Studi Kasus di Apotek Setya Sehat Semarang)," Journal of Informatics and Technology, vol. 2, no. 2, pp. 22 - 28, 2013.

[7] P. Safar Riduan Pasaribu, "Sistem Pendukung Keputusan Analisa Pola Penjualan Barang dengan Algoritma Apriori (Studi Kasus: Lucky Swalayan)," Pelita Informatika Budi Darma, vol. 6, no. 2, pp. 119 - 123, 2014

[8] Kusrini; Luthfi, Emha Taufiq;,Algoritma Data Mining, 1st ed., Theresia Ari Prabawati, Ed. Yogyakarta, Indonesia: Andi, 2009.

[9] Zulkarnain, IlmuMenjual (Pendekatan Teoritis\&Kecakapan Menjual), (Yogyakarta: Grahallmu, 2012), Ed. 1, Cet. 1, h. 9]

[10] Kotler, 2012, Manajemen Pemasaran Edisi12, Erlangga, Jakarta.

[11] Sibero, 2011, Kitab Suci Web Programing, MediaKom, Yogyakarta.

[12] Madcoms, L, 2011. Aplikasi Web Database dengan Dreamweaver danphp-MySQL. Yogyakarta: Andi.

[13] Arief, M, 2011, Pemrograman Web Dinamis Menggunakan PHP dan $M Y S Q L$, Andi, Yogyakarta.
[14] Nugroho, Bunafit. 2013. Dasar Pemograman Web PHP - MySQL dengan. Dreamweaver. Gava Media.Yogyakarta.

[15] A.S Rosa danSalahuddin M, 2015. Modul Pembelajaran Rekayasa Perangkat Lunak (Terstruktur dan Berorientas iObjek), Modula, Bandung. 